\title{
Consequences of Practical Polytheism in Human Deviation in the Qur'an and Nahj Al-Balaghah
}

\author{
Maryam Taebi \\ Email: Taebi2015@yahoo.com \\ http://dx.doi.org/10.18415/ijmmu.v9i2.3465
}

Tafsir and Quran sciences, Third level (M.S.); Qasim ibn al-Hasan seminary, Tehran, Iran

\begin{abstract}
Shirk (polytheism) literally means the combination of two properties and two shares. Practical polytheism means associating (a) partner(s) with God along side Him, and it is overt (Jali) and covert (Khafi) polytheism. Covert polytheism appears in the stage of worship and obedience to God such as Obedience to the mundane wish and desires (Havaye Nafs), obedience to the devil, following the tyrants; Worldliness, selfishness, pursuit of certain habits and tendencies common among some believers for example, friendship with the deniers of God, Prophets or infallible Imams (as); Humility and submission to non-God; Being a slave and captive of others ( being controlled by others ); Honoring the rich and the oppressors; Also hypocrisy and Sum'ah ${ }^{1} \ldots$. The present study entitled "Consequences of practical polytheism in human fall" with the aim of enlightenment in this field; in order to protect faith from the influence of superstitions and false heresies, has been carried out in narrative and descriptive methods. It is a library research which made references to the Holy Book of the Qur'an, Nahj al-Balaghah, some commentary books of Quran, theological, moral, and lexical books. Practical polytheism has consequences such as actions being void (Habt 'Amal); reduction of sustenance; anxiety and distress; shortening life in this world and the hereafter; going far from the mercy of God; the wrath of God in this world and the hereafter; wandering; lack of cheerfulness in worship, regret and so on.
\end{abstract}

Keywords: Consequences of Polytheism; Practical Polytheism; Human Fall

\section{Literature review}

The issue of practical polytheism has existed since the time of the Holy Prophet of Islam and has continued to this day among believers and various religions. About the literature review of the issue of practical polytheism in human deviation and its consequences among some faithful readers can refer to "The book of fixed principles of the life of the infallibles", by Muhammad Hasan Rabbani, consisting of 471 pages, pointed out how people perform in daily affairs and livelihoods, superstitious actions and the consequences of practical polytheism. The content of the mentioned book includes: 1- A look at the

\footnotetext{
${ }^{1}$ Doing good deeds so as people hear about
} 
manners and lifestyles of the infallibles in life 2- Mentioning superstitions and their impact on people's life. Readers can also refer to an article entitled "covert polytheism and its examples and consequences" written by Khalil Mansouri Ramsari on the Samamos site, which contains two types polytheism overt and covert, the hierarchical (longitudinal: Tuli طولى) order of means (Asb $\underline{a} b)$, and the issue of covert polytheism. Among its strengths, we can suffice to mention the effects of polytheism in the world and in the afterlife.

An article entitled "practical polytheism; The polytheism of the faithfuls" by Ali Mohammadkhani was published on 7/18/2010 in Keyhan newspaper, No. 19761, page 6. The text of this article consists of four parts: 1- Polytheism in actions 2- Polytheism in divinity 3- Polytheism in Lordship 4Polytheism in worship. One of the features of the mentioned article is paying attention to the four types of polytheism.

The difference between the present study entitled "Consequences of practical polytheism in human deviation in the Qur'an and Nahj al-Balaghah" with other studies is that: this research has expressed some common habits and tendencies among some believers in individual and social life that are consistent with practical polytheism. Also, expressing the consequences of practical polytheism of these tendencies from the perspective of the Qur'an and Nahj al-Balaghah, which is not mentioned in any of the mentioned studies, is a privilege of the present study.

\section{Conceptology}

\subsection{Polytheism (شرك:Shirk)}

Literally: polytheism means the merging of two properties and two shares.

As a Term: Polytheism means associating partners with God in His Lordship and dominion. (Raghib Isfahani, 2012, pp. 411-412)

\subsection{Sincerity ( اخلاص : Ikhlas)}

The opposite of polytheism is having sincerity in action.

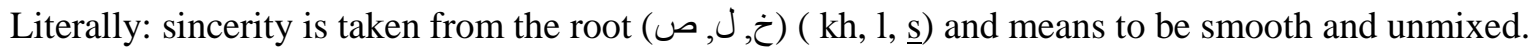

As a term: Raghib says: "Sincere is like smooth with the difference that sincere is what its combination has been lost, but smooth is sometimes said to have no combination at all" (Raghib Is 2012, pp. 411-412)

\subsection{Deviation, Fall, Error (ض , Dil)}

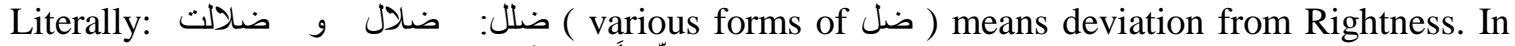
Surah 'An'am we read, “surely I see you and your people are in clear error." (6:74) deviation from Right path.

As a term: deviation from the right and sound path. (Raghib Isfahani, 2012, p. 473.)

\subsection{Guidance (ه , Huda )}

Literally: the past tense verb and in the word means " Guidance "هَدَايَة " with grace and kindness, and for this meaning it is "gift (aَدِيَّة " (a souvenir or a gift). 


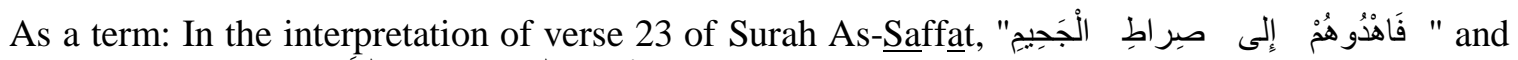

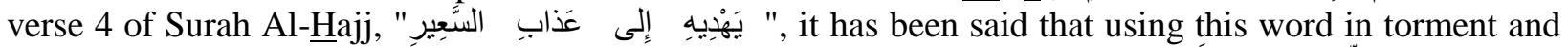

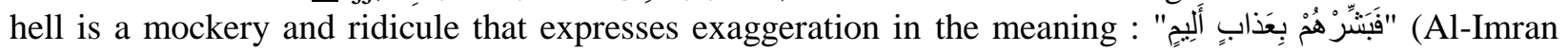
(3): 21; Bustani, 1997, p. 971)

"The giudance of God Almighty" has four aspects for human beings:

First: The general guidance (هدايت تكوينى) that is required by the creation of every creature, and in human beings, every obligated person and adult human being is inevitably dependent on that guidance

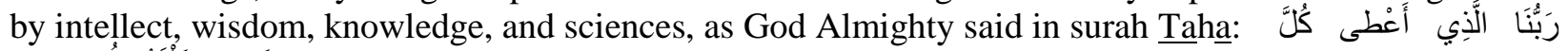
(20:50).

This verse is the argument of Prophet Moses (pbuh) to Pharaoh. That is, our God is the One who has given to everything that creation that guides him and brings him to perfection. And evolutionary guidance is like that nucleus in the soil whose root moves down and its stem moves up towatds out of the soil.

Second: Legislative guidance (هدايت تشريعى) that has reached the people according to the individual and social needs of human beings by the prophets and in the form of the Qur'an or other

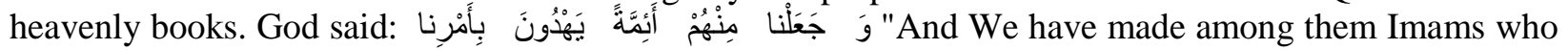
guide them by our commands." (Prophets (21): 73)

Third: The acquired ( Tawfiqi ) guidance (هدايت توفيقى), the foundation of which is prepared by man himself, this guidance is reserved for those who have moved on the path of guidance and perfection, God Almighty said:

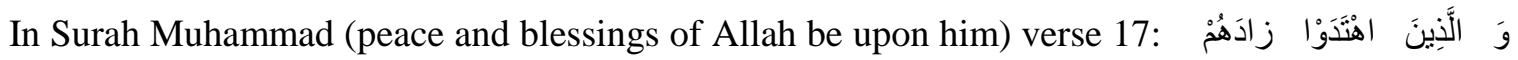
"A هدئ "And those who found guidance God increased their guidance." It is also stated in verse 69 of Surah Al-'Ankabut: وَ "And those who do jihad in our way, we will certainly

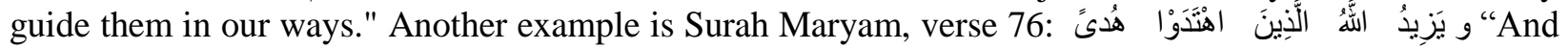
those who accept guidance, God increases their guidance." These verses indicate that first faith and goodness, then more guidance is from God.

Fourth: Guidance in the Hereafter towards Paradise and (reaching the Desired): verse 5 of Surah

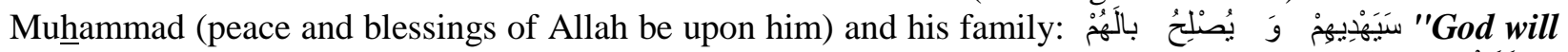
lead them to everlasting happiness and improve their condition." And verse 43 of Sura Al-A'raf: "We shall strip away all rancor from their chests. ... 'Praise be to Allah who

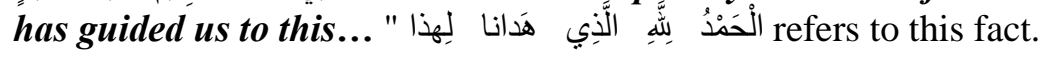

These four kinds of guidance are in the order in which they have been said, and each is a ground for the next one. One who does not have the first guidance, that is, the general guidance, does not reach the second guidance; And he isnot responsible for the second level and whoever does not reach the second guidance and does not achieve it will not enjoy the third guidance. (The ground should be provided by human beings with their faith, charity and hard work). Whoever reaches the fourth guidance means he has obtained all three previous guidance; the opposite may also happen, that is, one does not reach the second and third guidance from general guidance and does not perfect himself with his faith and goodness. No one can assist someone to reach the third level unless he is introduced to the ways. (Raghib Isfahani, 2012, pp. 515- 503.)

\subsection{Consequences}

What happens after or as a result of something (Anwari, 2004, p. 221) 


\section{Consequences of Practical Polytheism}

The present study has expressed some of the consequences of practical polytheism in society with the aim of eliminating polytheism and make some enlightenment in this type of polytheism from the perspective of the Qur'an and Nahj al-Balaghah.

\subsection{Friendship with the Deniers of God, the Prophets and the Ahl Al-Bayt (Peace Be Upon Them)}

Friendship requires love and expression of affection. How can a believer who has the love of God, the Prophets and the Ahl al-Bayt (as) in his heart love the deniers of God and the Ahl al-Bayt? If this is the case, one should doubt the faith of that believer; Because the love and friendship of God and the saints of God could not rest besides the love of their enemies and deniers. For this reason, it should be said that a person who befriends and associates with the opponents and deniers of monotheism and prophecy, his faith is mixed with polytheism, and his polytheism is a kind of polytheism in love.

Therefore, he cannot be considered as one of the monotheists and sincere people. Even if he has not endorsed their beliefs in his heart but the beliefs of the deniers may lead to a change in his behavior and beliefs after a while; if his faith is to the extent that no one can negatively influence him and hejoins the opposite group by the intention of influencing them, his friendship will be unimpeded and his sincerity and faith will not be disrupted.

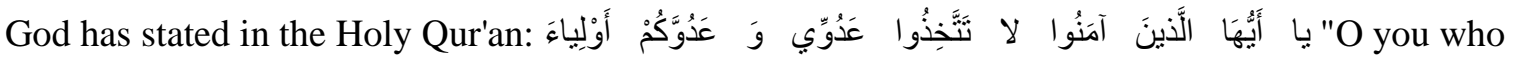
believe, do not take my enemy and your enemy as your friends, you make friends with them while they disbelieve in what has come to you from the truth." (Al-Mumtahana (60): 1) The reason of the revelation of the above verse is:

"An action was taken by one of the Muslims which, although not intentionally espionage, was considered an expression of love for the enemies of Islam, so the above verses were revealed and warned Muslims to avoid repeating such acts in the future. God first says: "O you who believe! do not take my enemy and your enemy as your friends. Only the enemies of God are hostile to you, how can you extend a hand of friendship to them?" Then he adds: would you offer them love while they deny what has come to you of the truth, driving out the Messenger and yourselves because you believe in Allah, your Lord. They oppose you in your belief and they have actually fought against you, and they have considered the work that is your greatest honor, that is, believing in God, to be your greatest crime and sin "(Bahrani, 1994, vol.5,p.325)

Imam Ali (pbuh) says about the characteristics of the friends of God and the Prophet in the wisdom of 432 Nahj al-Balaghah: "The friends of God looked into the world; When people looked at the appearance of the world and became interested in the future of the world and engaged in the fleeting affairs of the world. So they killed the Havaye Nafs and abandoned what was soon to leave them, despising the worldly people's benefit from the world, and considered their attainment to the world to be fleeting. They were enemy of what the pagans reconciled with, and reconciled with what the secularists were hostile to. The Qur'an is known by them and they are aware of the Book of God; The Qur'an is established by them, and they are based on the Book of God; And they do not look beyond what they hope for, and they are not afraid of anything but what they should be afraid of."

From the meaning of the short words of that Imam, it can be understood that the characteristics of God's friends are clearly different from the characteristics of God's enemies, and this conflict has made friendship between them impossible.

Elsewhere, in the letter 15/69 of Nahj al-Balaghah, Imam 'Ali emphasized: "Avoid associating with the wicked, in which case evil joins evil. Glorify God and consider God's friends as your friends." 
The result is the need for friendship with God is friendship with the Holy Prophet of Islam, in such a way that the believer loves him more than anything and everyone, and to be friends with the Holy Prophet of Islam, one should be friend with the Ahl al-Bayt (as) and their relatives (Shura (42): 23) in such a way that the heartfelt love for them is more than the love for his own family members. Also the prerequisite of friendship with the Lord of the universe is to love His religion and obey Him and to love the abode of the Hereafter. In such a way that even if his life is harmed by this friendship, he will not give up loving the only God,

Such is the state of the believer; whoever is in accordance with what has been said in the verses of Quran, find salvation, and if it is otherwise, in the sense that he has the love and affection of the deniers and the enemies of God and seeks lusts and mundane desires, such a person is one of the wicked; Because he has lost the path of salvation and has gone out of the command of God Who orders faith and interest in the Prophet and Ahl al-Bayt, and according to the verses, the wicked one is deprived of divine guidance and care. (Munafiqun, (63): 6)

\subsection{To Be Humble and Submissive to Other Than God}

Raghib has stated in "Mufradat", "submission ( خُضُوع Khudu') is the same as humility ( خشوع , khushu') that is, obedience and meekness, and "الخَثْيَة 'al-Khashyah" is the fear that is associated with reverence and glorifying something, and most of this state is acquired through knowledge and awareness of the cause of fear and reverance.”( Raghib, 2012, pp. 605-609).

It deserves that fear, reverence, humility and submission be limited to God Almighty and nothing else. Countless verses in the Holy Qur'an, addressed to the great Prophet of Islam, state that "O Prophet, it is desearved you fear God only..." (Al-Ahㅡㅁㅡ (33): 37)

Bowing and honoring and fearing others for worldly interests is forbidden by God Almighty. A believer who considers God to be All-Wise in all the affairs of the universe and is sure that God surrounds all the affairs of the universe, and if He does not want to, no means will have influence and survival in the world, never place, fear and dread in his heart, except the fear and dread of God Almighty, and if he does, he has given God a partner, in this case he must repent, ponder and reflect on his deeds, and asks God help him to overcome the weakness and deficiency in his faith. It should be noted that expressing politeness in front of the Prophet and the Ahl al-Bayt (as) and the position of professors in order to honor their position is one of the matters approved by God Almighty, and such statements do not contradict the fear of God. Honoring and expressing love to the Holy Prophet (peace and blessings of Allaah be upon him) has never meant we consider him as God. Also, issues such as composing poems in the praises of infallibles, preserving whatever remains from Prophethood and making shrines are neither polytheism nor heresy; it is not polytheism because the source of deeds is love and affection for the saints not believing in their Lordship. And it is not heresy; because these acts have a Quranic and hadith basis, which is the principle of the necessity of loving and being kind to the Prophet and his family. The honorable deeds of the believers on the days of infallibles' birth and Be'that of Prophet are a manifestation of this friendship, and in return, the submission and prostration of the polytheists to the idols is forbidden and rejected because it stems from the belief in their Lordship and the polytheists know honor, humiliation, forgiveness and intercessionin their hands. (Subhani, 2011, p. 52)

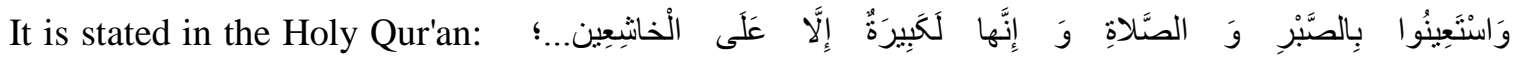
"And seek help in patience and prayer. For it is heavy, except to the humble" (Surat al-Baqara (2): 45) the verse explicitly expresses humbleness should be only towards God.

It is narrated from the Commander of the Faithful Ali (as) that: "In verse 45 of Surah Al-Baqarah, prayer is the establishment of my guardianship (Villayat); That is why he said: Doing it (إنَّها $)$ refers to the guardianship of him.) It is heavy and difficult, and He did not say that the two (patience and prayer are 
difficult) because accepting and carrying the province (Villayat) is heavier than prayer and patience and the humble people are our insightful Shiites." (Majlisi, 1984, vol. 1, p. 153)

\subsubsection{The Relationship Between Humility and Obedience}

Humility is a state of refraction in the organs and joints of the body. It is narrated that a person prays and plays with his beard. The holy Prophet said, "if his heart was obedien, his organs were obedient too." That humility is called obedience that has an effect in practice, as opposed to obedience, which means a kind of inner influence that arises from seeing the greatness and arrogance of God in the heart." (Tabatabai, 1996, vol. 16, p. 166; Tayyib, 2000, vol. 9, p. 356)

Among the factors of obedience are reciting the Qur'an (Isra' (17): 109) and believing in the Resurrection (Baqara (2): 46); And Mustahab obedience which is stated in some narrations and jurisprudential books, is expressing obedience for some Mustahab (recommended) affairs, including: when entering the mosque, the shrine of Mecca, the city of Mecca, Masjid al-Haram and the Ka'aba (Zin al-Din, vol. 1, p. 186), also attending the glorious shrines of the Infallibles (peace be upon them) and during their pilgrimage, when reciting the Qur'an and reciting dhikr and reciting prayers, when going out into the desert to perform the prayer of Istisqa'. (A group of researchers, 2005, vol. 1, p. 390) and when the worshiper enters his prayer hall, during his pray, especially while standing up in prayers should humbly look at the place of his prostration, as well as in Tawaf and I'tikaaf. (Hilli, 1991, vol. 5, p. 212; Kabuli, 2005, p. 64) God said:

Imam 'Ali (pbuh) in sermon 79 of Nahj al-Balaghah about avoiding paying attention to other than

Do you think you can tell the time when a man goes out and no evil befall him or can warn of the time at which if one goes out harm will accrue? Whoever testifies to this falsifies the Qur'an and becomes unmindful of Allah in achieving his desired objective and in warding off the undesirable. You cherish saying this so that he who acts on what you say should praise you rather than Allah because according to your misconception you have guided him about the hour in which he would secure benefit and avoid harm.

The result: Man is a part of the components of the universe which, like all those components, is under the divine providence and realizes the end for which God has determined and destined, and no creature of the universe intervenes and rules in His plan, and the causes which seem to be effective in the world all are from Him, and none of them are independent. If a person is humbled in the face of these causes and means, and this humility keeps him away from the real Cause, even though he is a believer, his faith is tainted with polytheism and his deeds are ineffective and he will not be rewarded.

\subsection{Being a Slave and Captive of Others}

Servant means slave, the opposite of a free person. He who is very powerless against someone or something, is subdued ... (Anwari, 2004, p. 154)

The condition of being Monotheist is that man should be a servant and obedient to God Almighty, consider His $\underline{\boldsymbol{H}}$ alal as Halal and His $\underline{\boldsymbol{H}} \boldsymbol{a r} \underline{\boldsymbol{a}} \boldsymbol{m}$ as Haram. Be submissive to the commands of the Almighty in all religious orders. The Able creator in Whose Hands is everything and $\mathrm{He}$ is the master of the affairs of the universe. So, if a person is a slave and captive of idols and demons or lusts or a captive and slave of their greed or a follower of famous people in today's society who only seek to show off and satisfy their worldly needs, etc.; In that case, he is certainly considered a partner in obedience to God, and the type of this polytheism is polytheism in obedience. The monotheist believer does not look for anything but the satisfaction of the Almighty and does not forget remembering of God for a moment of and considers only 
His Excellency as effective in the affairs of the world and work in the world for the Hereafter and is not ignorant of the most important things, that is, death and entering the world of the grave and purgatory.

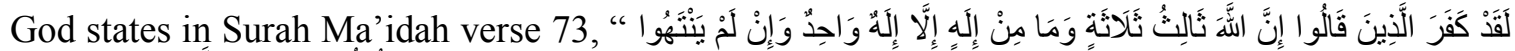

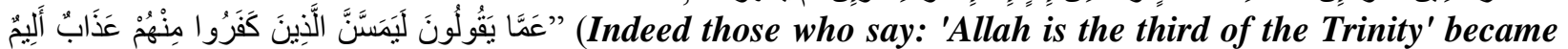
unbelievers. There is but One God. If they do not desist in what they say, a painful punishment will afflict those of them that disbelieve.) (5: 73)

\section{2-4-1. Consequences of Polytheism in Obedience}

This study has expressed some of the consequences of practical polytheism in society with the aim of eliminating polytheism and enlightenment in this type of polytheism from the perspective of the Qur'an and Nahj al-Balaghah.

\subsubsection{Deprivation of Divine Knowledge}

One of the important principles is that God does not mislead anyone in the first place and does not withhold His grace from anyone, even from polytheist. Therefore, if it is said God has misled some, it means the punishment that is given to sinner due to his stubbornness by which he deprives himself from God's special mercy and guidance.

\subsubsection{Division and War}

Monotheism is the cause of unity and harmony, and polytheism is the cause of division and dispersal. Polytheism can never be a cause of unity and empathy because it is the result of idolatry and idolatry is always a function of lust and rage.

\subsubsection{Humiliation and Ignomity}

God says in the Qur'an: "Do not set up with Allah another god, or you will sit condemned and forsaken." (Isra '17:22) This verse means polytheism is a source of weakness, inability and condemnation; Because the pagans kill their intellect with idolatry and turn to things that the intellect rebukes and reprimands. As a result, God leaves man to his god and removes His supportive Hand from him, and as a result, he is humiliated.

\subsubsection{Habt 'Amal}

$\underline{\boldsymbol{H}} \boldsymbol{a b t}$ 'Amal means erasing deeds; Because the condition for accepting deeds is belief in the principle of monotheism, and without which no action is acceptable. The polytheism is a burning fire that burns the pile of man's deeds and burns the whole product of his life. (Makarem Shirazi, 1988, vol. 19, p. 527)

Sermon 149, known as the last sermon of Imam 'Ali (pbuh) which, according to the noble book of Nahj al-Balaghah, was delivered after his striking by sword and before his martyrdom, says, "As for my last will, it is that concerning Allah, do not believe in a partner for Him, and concerning Muhammad (S), do not disregard his Sunnah. Keep these two pillars and burn these two lamps. Till you are not divided, no evil will come to you. Every one of you has to bear his own burden. It has been kept light for the ignorant."

Elsewhere, he has said, "Greed is perpetual slavery." It is obvious that greed in worldly affairs and indulging in whims and desires are among the things that lead to slavery and captivity of human beings; as after the enslavement of the soul, polytheism naturally happens. (Nahj al-Balaghah, Wisdom 180) 
The result is God Almighty has forgiven the servants when they forget Him other than the times He has appointed for worship in case that they do not worship another god and not be slave of others; Therefore, a person who is a servant of Havaye Nafs and controlled by the devil from morning to noon, and when it is noon, he remember it is time to do prayer, no matter how well he performs the prayer, he is not truthful in the position of servitude and is suffering from polytheism, therefore, he will never be one of the pure servants in the sight of God; the prayer of such a person is not pleasing to God and that prayer will not bring him to the degree of nearness to God. He only has done his duty of saying prayer.

\subsection{Honoring The Rich and The Tyrants}

Another thing that removes man from the ranks of the monotheists and the pious ones is the honoring the rich and the tyrants, which spreads in human societies today. Some consider wealth as a means of their pride and consider the poor and middle classes of society as low and unimportant. And some others turn to them to benefit, revering them by their words and deeds, and cherishing them; If this reverence for the wealthy and the idolaters originates from the heart of the believer, undoubtedly, his faith will be mixed with polytheism, but if this respect is not for the sake of wealth, but only for the sake of the piety of the wealthy person, not because of his wealth, then humbleness in front of him is not a problem, because humbleness towards religion is humbleness for God.

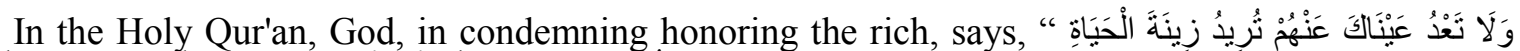

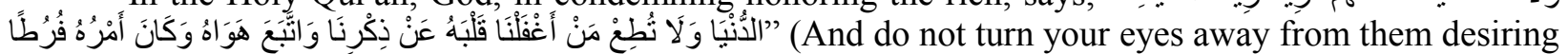
the good things of this life, nor obey he whose heart We have made neglectful of Our remembrance; so that he follows his own lust, and his affair has become excessive.) (Kahf (18): 28)

Throughout history, the affluent people and the wealthy infidels have always brought up a condition to accept a religion and that condition was the rejection of the poor and needy people; as the followers of Prophet Noah (peace be upon him) asked him to do so, and the Prophet replied, وَمَا أنَا بطَّارِدِ

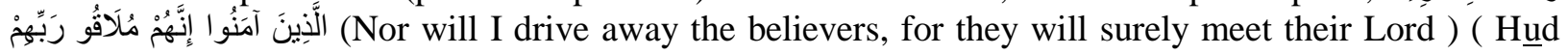
(11):29) At the time of the Prophet of Islam (peace be upon him and his family), he was also asked to expel the poor such as Salman, Abu Dharr, 'Ammar, etc. from himself so that the affluent figures would believe and join him. This verse condemns such thinking and action.

According to the Qur'anic verse of the Qur'an, "If Allah had expanded His provision to His worshipers, they would become tyrannical in the earth." (Al-Shura (42):27) The Holy Prophet of Islam (peace be upon him and his family) said: "What I am very afraid of concerning these people is that one day, the property of some of them will increase so they compete, be jealous of each other, be greedy, boast in wealth and in fassilities and kill each other. (Varam Ibn Al-Faras, 1990, vol. 1, p. 127) Boasting is one of the pests of amassing wealth. The man who does not pay attention to divinity likes to brag to others about the blessings God has given him.

The Holy Qur'an says in this regard: "Despite this, the human being still tends to rebel, because he thinks that he is independent." ("Alaq (96): 6-7) By comparison, it may be said wealth will lead to larger-scale outbreaks than poverty. The spirit of the teachings of Islam, while respecting private property and encouraging the pursuit of lawful wealth, does not agree with the absolute polarization of society and the accumulation of wealth. Basically, in the collection of Islamic teachings, affairs are designed in such a way that if one wants to observe one hundred percent of principles of Sharia concerning Halal and Haram, adheres to all moral matters, observes Sharia taxes, and follows the advice of Islam in terms of consumption and expenditure of property, abundant windfall wealth of him will never cause social and economic corruption. "Islam forbids hoarding wealth and storing it, and considers this act as blood clotting in the arteries of the human body, which causes paralysis of other organs, so regards its flow and movement necessary. (Javadi Amuli, 2016, p. 108) 
One of the important issues in the life of Imam Ali (as) is his behavior with the enemies and worldly people. Imam Ali (pbuh) faced enemies that the Prophet (pbuh) did not face. The Prophet confronted those who said long live the idols with his words and behavior! They used to say, but Imam Ali (pbuh) was faced with a group of people who had a brilliant record in serving Islam! They were people of worship and the Qur'an and staying up nights to pray (like Talha and Zubayr), however, they were unaware of the spirit of the school of Islam, and preferred the interests of this world and amassing wealth over their hereafter, and these matters paved the way for their confrontation with the just rulership of Imam Ali (pbuh). The Imam were in fact confronted with hidden hypocrisy, and it is clear that dealing with these enemies is much more difficult than dealing with the infidels. For this reason, Imam Ali (pbuh) considers dealing with such enemies as one of his honors. (Nahj al-Balaghah, Sermon 93) Imam Ali (pbuh) in his condemnation of honoring the rich said: "I am the leader of the believers and the rich are the leader of the corrupt" (Subhi Al-Saleh, 1986, Wisdom 316, p. 530)

Sayyid Radi says, "The meaning of the Imam's words is that the believers follow me and the evildoers follow the wealth as the bees obey their leader."

The result is those who are polite and humble with their tongues and bodies in front of the rulers and the affluent people, while they consider themselves monotheists and Shiites, according to a hadith from Imam Ali (pbuh), "One who faces the rich and is humble with his tongue and body in front of him, has lost Two-thirds of his faith." (Subhi Al-Saleh, 1986, Hekmat 228). Therefore, if a person is humbled in front of the rich by his tongue and body and also feels humble in his heart, he has lost all his faith. So judge what fate awaits the one who dies irreligious in the Hereafter?

\section{Conclusion}

The results obtained from the present study entitled the consequences of practical polytheism in human deviation in the Qur'an and Nahj al-Balaghah are as follows: Polytheism literally means associating and equating a deity or deities alongside the One God. Covert polytheism has different types: a) Polytheism in obedience and it is obedience to the Havaye Nafs, the devil and the idols. b) Polytheism in worship such as hypocrisy and Sum'a ... . Practical polytheism is one of the types of covert polytheism that most believers suffer from. The consequences of practical polytheism are:

1- Misguidance and deviation in this world and the hereafter 2- Turning away from God's mercy 3- Habt 'Amal 4- Loss in this world and the hereafter 5- Humiliation and rebuke by God in the Hereafter 6- Reduction of sustenance 7- Shortness of life time 8- Divine torment 9- Regret in the Hereafter 10Falling from the level of humanity 11- Deviation from religion and spearding heresy in society.

Every negative habit that a person tries to do, such as: submission and obedience to other than God; Being a slave and captive of others; Friendship with the deniers of God, the Holy Prophet of Islam or the infallible Imams (as); The glorification of the rich and the tyrants are derived from a negative trait (Razilah), which is the origin and sign of practical polytheism, the recognition of which requires attention and reflection. In order to get rid of polytheism from deeds, actions and heart, one should seek help from God Almighty in this way and ask the Holy Lord to place him among the sincere ones in the court of God.

What has not been addressed due to the limitations of the research is not to mention and express all the habits and examples of practical polytheism in human error and their consequences. 


\section{Sources}

Quran

Nahj al-Balaghah

A group of scholars, (2005) the culture of jurisprudence according to the religion of the Ahl al-Bayt (as), Qum: Muassissah of Encyclopedia of Islamic jurisprudence on the religion of the Ahl al-Bayt (as).

Anwari, Hasan (2004) Farhange Koochak Sokhan, Tehran: Sukhan pub.

Bahrani, Hashim Ibn Sulayman (1994) Al-Burhan Fi Tafsir Al-Quran, vol.5, first edition,Qum: Muassissah al-Bi'thah, Al-Durasat al-Islamiyah

Fu'ad Bustani, Afram, (1997) Farhang Abjad, second edition, Tehran: Islami, in Noor software, Qamus Quran.

Hilli, Hasan Ibn Yusuf Ibn Mutahhar (1991) Muntahi al-Matlab fi Tahqiq al-Madhhab, Mashhad: Majma' al-Buhuth al-Islamiyah.

Ibn Babawayh, Muhammad Ibn Ali Ibn Al-Husayn (1999) Ma'ani $\underline{i}$ Al-Akhbar, translated into Farsi by 'Abdul Ali Muhammadi Shahroudi, Tehran: Nashr Dar al-Kutub al-Islamiyah

Javadi Amuli, ‘ Abdullah (2004), Tawhid in the Quran, first edition, Qum: Isra ' Publishing.

Javadi Amuli, Villayat Faqih, Villayat, Jurisprudence and Justice, Qum: Isra ' Publishing.

Kạbuli, Muhammad (2005) Rites of $\underline{H} a j j$, Qum: Author

Lankarani, Muhammad Fadil (2006) I'tikaf and its A $\underline{h} k a m$, vol. 1, Qum: Jurisprudential Center of the A'imih Athar

Majlisi, Muhammad Taqi (1984) Bihar Al-Anwąr, vol. 26, Beirut: Al-Wafa Institute

Makarim Shirazi, Nạir (1988) Tafsir Nimuneh, Vol. 19, vol. 4, Qum: Dar Al-Kutub al-Islamiyah

Raghib Isfahani, ㅂusayn Ibn Muhammad (2012) Mufradat, fourth edition, Qum: Navid Islam

Shahid Thani, Zayn al-Din ibn Ali (1991) Al-Rawdha al-Bahiyya fi Sharh al-Luma'ah al-Damashqiyyah, vol. 1, Qum: Publications of the Office of Islamic Propaganda

Sharị ati Sabzevari, Muhammad Baquir (2002) Tawhid, polytheism and hypocrisy, the journal of Let's get acquainted with Islamic education, No. 53

Subhani, Ja'far (2010) Imamate Beliefs, Qum: Imam Sadiq Institute Publishing.

Subhi, $\underline{\text { Salih }}$ (1986) Nahj al-Balaghah, Qum: Dar al-Hujra

Tabatabai , Muhammad Husayn (1995) Tafsir Al-Mizan, vol. 1, ch.5 Translated into Farsi by Seyyed Muhammad Baqir Mousavi Hamedani, Qum: Islamic Publications Office of Qum Seminary Teachers Association.

Tayyib, 'Abdul Husayn (1999) Atyab al-Bayan fi Tafsir al-Quran, vol. 9, ch. 2, Tehran: Islam Publications 
Waram Ibn Al-Faras, Mas'üd Ibn 'Isa (2018). Al-Waram Collection; Etiquette and ethics in Islam, translated into Farsi by Muhammad Reza 'Ataii, vol. 1, Mashhad: Astan Quds Razavi Publishing, Islamic Research Foundation.

\section{Copyrights}

Copyright for this article is retained by the author(s), with first publication rights granted to the journal.

This is an open-access article distributed under the terms and conditions of the Creative Commons Attribution license (http://creativecommons.org/licenses/by/4.0/). 